\title{
Bank Size, Capital Buffer, Efficiency, and Liquidity Risk in Indonesia Banking Industry
}

\author{
Lasty Agustuty \\ Management Study Program \\ STIE Tri Dharma Nusantara \\ Makassar, Indonesia \\ Muhammad Ali \\ Economics and Business Faculty \\ Hasanuddin University \\ Makassar, Indonesia
}

\author{
Abdul Rakhman Laba \\ Economics and Business Faculty \\ Hasanuddin University \\ Makassar, Indonesia \\ Muhammad Sobarsyah \\ Economics and Business Faculty \\ Hasanuddin University \\ Makassar, Indonesia
}

\begin{abstract}
The purpose of this study is to obtain empirical evidence of the influence of bank size, capital buffer and efficiency on liquidity risk. The research sample is a Conventional Commercial Bank that has a bank asset ratio value above $2 \%$ of total national banking assets and publishes financial statements in full during 2004-2019. Data analysis techniques in this study are panel data regression of EViews software. The results showed that bank size has a positive and significant influence on liquidity risk. Capital buffer has a positive and significant influence on liquidity risk. Efficiency that measured byBOPO ratio have a positive and significant influence on liquidity risk.
\end{abstract}

Keywords:- Bank Size, Capital Buffer, Efficiency, Liquidity Risk.

\section{INTRODUCTION}

Banks act as financial intermediary institutions, providing liquidity transformation from depositors to debtors who need funds for various purposes. The strength of the banking system is an important requirement to ensure stability and economic growth because banks hold a market share reaching up to $79 \%$ in the Indonesian financial system, (Helen, 2018).

In an effort to carry out its functions properly, the banking sector is required to be able to effectively manage the risks so that the financial intermediation process in the economy can be sustained and run efficiently. Schinasi (2005) revealed one possibility of financial instability that is sourced from liquidity risk. The more liquid a portfolio managed by a bank, the greater the price impact caused when sudden liquidation occurs. Furthermore, Billio et al. (2010) stated that market movements which are driven by liquidation difficulties can escalate into a broader financial crisis. As was the case in 2008, the banking crisis in Indonesia during the global crisis caused the government to bear the costs of Rp 15 trillion as liquidity assistance for three large-scale national banks, Bank Mandiri Tbk, Bank BNI Tbk, and BRI Bank Tbk
Liquidity risk is a financial risk due to liquidity uncertainty. Kapadia et al. (2013) shows that liquidity problems experienced by a bank can make the bank do liquidity hoarding that disrupts the availability of liquidity for other banks. This event can trigger other banks to enter into liquidity problems or into a panic situation that eventually leads to a crisis.

Large banks usually have more loans and a larger financing gap. This can trigger banking liquidity problems. Asset structure is very influential on the amount of profit generated. If the largest portion of assets is receivables from lending, then receivables from lending (the current category or performing loans) will increase the income received because these performing loans are incomegenerating assets in the form of interest income (Wild at all, 2010). If it turns out that the loan portion is not smooth, it will affect the bank's income, causing a decrease in capital so that any increase in assets or total assets will cause a decrease in liquidity. Contrary to research conducted by Zolkifli at all, 2015), finding bank size and liquidity has a positive relationship.

Too Big To Fail (TBTF) concept is inherent in financial institutions that manage large assets, have a large relationship with other financial institutions, and provide significant financial services. The large size of the bank allows the bank to provide a broader menu of financial services, creating the complexity of the bank's business activities. The size of the bank's assets does not guarantee that the bank will be safe from the brunt of the liquidity crisis and even systemic risk. Rajan and Roubini (2010) and Gnaizda (2009) found that the problem of TBTF bank assets which is always used as an attraction for consumers to attract customers is not a guarantee that the bank is "immune" from the global financial crisis.

Another thing that exacerbates the crisis situation is because bank capital buffers cannot absorb failures by banks in crisis, and it is likely that this will also happen to a series of banks that have a relationship in loan repayments on the interbank money market. The crisis that occurred in 2008 was also motivated by over-leveraging behavior that was not matched by strong capital and liquidity, which caused banks to be unable to absorb losses and disruptions. 
Bank soundness indicators also play an active role in minimizing liquidity risk. Bank health can be seen from the achievement of bank efficiency. The impact of liquidity risk can be avoided by increasing bank efficiency, in addition, inefficient banks can increase the potential for systemic risk. The level of bank efficiency can be measured by the BOPO ratio. Greenspan (2012), Bernanke (2012), and Roubini and Rajan (2012) research found that one of the causes of liquidity crisis in American and European banks was caused by the existence of inefficiency. Contrary to research by Sobarsyah (2014) on the national banking industry because efficiency does not have a strong effect on liquidity risk.

Based on the background above, the formulation of the problem in this study is whether the bank size measured by total assets, capital buffer, and efficiency measured by BOPO ratio affect the liquidity risk of the bank. The purpose of this study is to obtain empirical evidence of the influence of bank size, capital buffer, and efficiency measured by BOPO ratio affect the liquidity risk of the bank.

\section{LITERATURE REVIEW AND "HYPOTHESES" DEVELOPMENT}

\section{A. Too Big To Fail (TBTF)}

Too Big To Fail (TBTF) is a term in the economic and financial fields that refers to several institutions or business entities. The concept of Too Big To Fail refers to a bank that faces liquidity problems and has a systemic global effect. The Doctrine of Too Big To Fail (TBTF), began during Lois Brandeis, in 1914. Treasury took steps to provide financial assistance to New York City.

The experience of the 2008 global financial crisis caused by the bankruptcy of investment company Lehman Brother Holding Inc. provides a lesson that the failure of financial institutions that have a systemic impact globally needs to be structured. The bankruptcy of the company turned out to cause systemic failure not only in the United States but also had an impact on the global (world) financial crisis, including in Indonesia. However, another fact confirms, that from January to December 2009, more than 100 banks have been closed, but did not cause systemic impacts. This indicates that failure of an institution does not necessarily lead to systemic risk. Generally banks that pose systemic risk are large banks that can drag other banks into default. Banks with very large systemic impacts are known as Too Big To Fail, too risky for the government and monetary authorities to let this bank suffer from default.

Stern and Feldman (2004) define TBTF as a government policy towards the protection of large-scale companies that experience financial and operational problems. Sorkin (2010) states that TBTF is a government stabilizer to save economic conditions. TBTF's view or too big to fail illustrates the belief that if a large company fails, it will have a disastrous wave effect on the entire economy, so rescue efforts are made to reduce the domino effect for other companies if a large company experiences liquidity problems.

\section{B. Charter Value Theory}

Quoted in Nooren at all (2016), the Charter Value Theory developed by Marcus in 1984 explains that banks always hold extra capital to secure them from decreasing stability and handle the risk of business failure. Charter value theory also predicts that banks will face a loss in their income in the future if a bankruptcy occurs and the impact of these losses hits many parties including shareholders. Therefore, the bank will maintain its capital in excess of the required minimum capital.

\section{Effect of Bank Size on Liquidity Risk}

One of the causes of systemic risk based on Bank Indonesia Regulation (PBI) No.16 / 11 / PBI / 2014 is the interaction of bank size factors. The size of the bank scale reflects the total assets and the number of deposits owned by the related bank. The greater the number of assets owned, the risk of systemic impact if experiencing problems is higher.

The large size of the bank allows the bank to provide a broader menu of financial services, creating the complexity of the bank's business activities. The size of the bank's assets does not guarantee that the bank will be safe from the brunt of the liquidity crisis and even systemic risk. Rajan and Roubini (2010) and Gnaizda (2009) found that the problem of TBTF bank assets which is always used as an attraction for consumers to attract customers is not a guarantee that the bank is "immune" from the global financial crisis. Sobarsyah (2014) explains that the crisis affecting top financial institutions in America and Europe actually affects TBTF banks, where the volatility of these banks assets has a negative impact on liquidity risk and ultimately triggers systemic risk that begins with the collapse of the top financial industry. in America, Lehman Brothers which created a domino effect on other global financial industries.

Delechat (2012), states that smaller banks tend to have higher liquidity reserves. This can be motivated by the financial limitations of small banks in obtaining funds so that small banks tend to hold higher liquidity. Meanwhile Vodova's (2013) research is in line with the principle of "too big to fail", where large banks that are considered too big to be able to fail will be more trusted by lenders, so large banks tend to have limited motivation to hold high liquidity reserves.

Hypothesis 1: Bank size has a positive effect on liquidity risk

\section{Effect of Capital Buffer on Liquidity Risk}

Banks with strong capital are able to support bank operations and reduce the risk of bankruptcy and loss, avoid liquidation and bankruptcy as well as capital to be able to compete in global competition (Deelchand, 2009). The amount of capital owned by the bank effectively protects the depositor against bank failures. 
ISSN No:-2456-2165

Based on the importance of capital for banks, banks not only try to meet the minimum CAR requirements but also try to increase the CAR above the minimum. Bank CARs above a minimum function in mitigating risks from the business cycle. The difference between the CAR provisions or the minimum capital adequacy ratio set by the bank-owned CAR (above the $8 \%$ requirement) is known as the Capital buffer. Capital buffer in the banking industry serves to anticipate if there is an increase in future losses and to anticipate if capital becomes scarce and expensive.

Hypothesis 2: Capital Buffer has a negative effect on liquidity risk

\section{E. Effect of Efficiency (BOPO ratio) on Liquidity Risk}

BOPO has a big influence in measuring the level of efficiency and also the ability of banks to run their operational activities. The higher the level of efficiency of a bank, the healthier the bank. According to Berger and Deyoung (1997), in the Bad Management Hypothesis, efficiency (BOPO) will be a signal that banking management in achieving performance is going well. If a bank can increase its efficiency, the bank's chances of being affected by liquidity risk are very small. The efficiency aspect really needs to be emphasized in the application of banking risk management. This was confirmed by Greenspan (2012), Bernanke (2012), as well as Roubini and Rajan (2012). They found that one of the factors causing the liquidity crisis that occurred in American and European banks was due to inefficiency problems.

Based on the description above, the conceptual framework model in this study can be formed as follows:

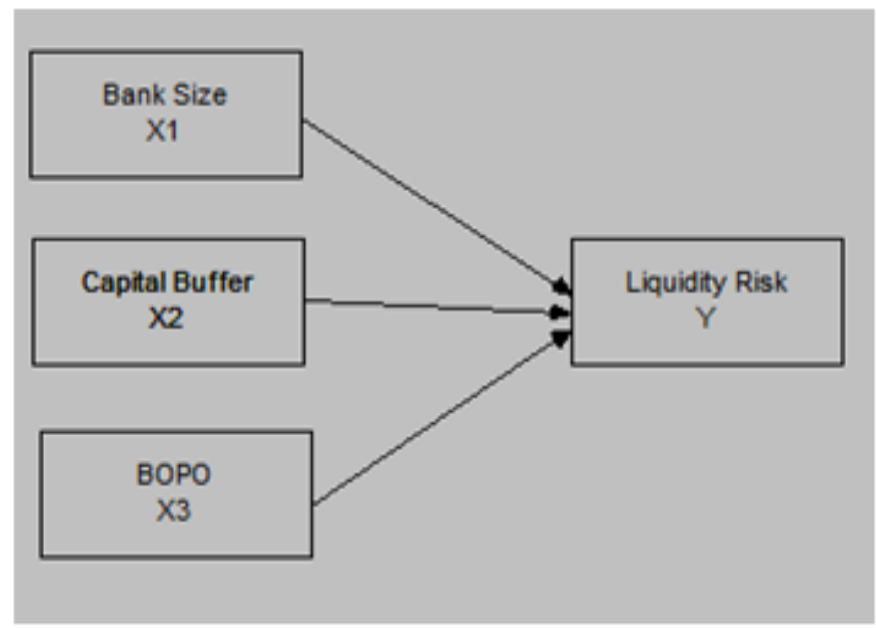

Fig 1:- Conceptual Framework

\section{METHODOLOGY}

\section{A. Population and Sample}

The Population is the total number of groups of individuals or the overall object of research. The population in this study are all banks operating in Indonesia. The sample is part of the population that will be studied and is considered capable of representing the population.

The sampling technique in this study used a purposive sampling technique, which is sampling with certain considerations and criteria in accordance with the objectives of the study. Banks that will be used as research samples are banks that have the following criteria:

$>$ Conventional Commercial Banks

$>$ Banks publish financial statements in full during 20042018

Banks that have a bank asset ratio value above $2 \%$ of total national banking assets
Have complete data in accordance with the variables studied in this study. Based on the sampling criteria above, the banks that meet the requirements for use as samples in this study are 10 banks from 2004-2018.

\section{B. Types and Sources of Data The}

Types of data used in this research are documentary data in the form of bank financial statements for the period 2004-2018. While the data sources used in this study are secondary data in the form of figures in annual financial reports obtained from the Financial Services Authority (OJK), Bank Indonesia (BI) or from their respective Banks.

\section{Operational Definition of Variables}

Definition of the variable aims to explain the meaning of the variable being studied, while the operational definition of the research variable is described in Table 1 as follows: 
ISSN No:-2456-2165

\begin{tabular}{|c|c|c|c|}
\hline No. & Variable & Definition & Measurement \\
\hline 1 & Bank size (X1) & $\begin{array}{c}\text { Number of assets owned by bank log } \\
\text { total asset }\end{array}$ & Total Asset \\
\hline 2 & Capital buffer (X2) & $\begin{array}{c}\text { The difference between the ratio of } \\
\text { capital owned by the Bank with the } \\
\text { minimum capital requirements required }\end{array}$ & $\begin{array}{c}\text { Capital Buffer = CAR ratio - Minimum Regulatory } \\
\text { Requirement (8\%) }\end{array}$ \\
\hline 3 & $\begin{array}{c}\text { Efficiency (X3) (BOPO } \\
\text { Ratio) }\end{array}$ & $\begin{array}{c}\text { To measure the level of efficiency and } \\
\text { the ability of banks to carry out } \\
\text { operational activities. }\end{array}$ & $\begin{array}{c}\text { BOPO= }= \\
\text { Pendapatan Operasional }\end{array}$ \\
\hline 4 & Liquidity Risk (Y) & $\begin{array}{c}\text { The risk of the inability of banks to } \\
\text { meet obligations due from cash flow } \\
\text { funding sources, and / or from high } \\
\text { quality liquid assets }\end{array}$ & $\begin{array}{l}\text { liquidity risk } \\
\text { liquid asset - short term borrowing }\end{array}$ \\
\hline
\end{tabular}

Table 1:- Operational Definition of Variables

\section{Data Analysis Techniques}

By referring to the conceptual framework stated earlier, the method chosen for data analysis in this study is Panel Data Regression with the help of EViews software.

\section{RESULTS AND DISCUSSION}

This study used a sample of 10 banks in 2004-2018 to form 150 data. The following descriptive statistics of each variable of the study:

\begin{tabular}{|c|c|c|c|c|}
\hline & $\mathrm{X} 1$ & $\mathrm{X} 2$ & $\mathrm{X} 3$ & $\mathrm{Y} 1$ \\
\hline & & & & \\
\hline Mean & 32.80973 & 11.15460 & 82.50560 & 34.60687 \\
\hline Median & 32.79000 & 9.360000 & 80.08000 & 32.53000 \\
\hline Maximum & 34.80000 & 45.84000 & 178.4300 & 87.75000 \\
\hline Minimum & 30.81000 & 1.800000 & 42.00000 & 5.700000 \\
\hline Std. Dev. & 0.928257 & 7.012809 & 24.73333 & 17.31876 \\
\hline Observations & 150 & 150 & 150 & 150 \\
\hline
\end{tabular}

Table 2:- Statistics Descriptive Research Variables Source: Output Eviews

Based on Table 2 can be described as the variables used in the study as follows:

$>$ The bank size variable has a minimum value of 30.81 and a maximum value of 34.80 . This means that from the 150 observational data the lowest bank size value was 30.81 percent and the highest value was 34.80 percent. The average value of the bank size is 32.81 percent with a standard deviation of 0.93 . The standard deviation is smaller than the average value, indicating the bank size variable is normally distributed.

The variable capital buffer has a minimum value of 1.80 and a maximum value of 45.84 . This means that the lowest capital buffer value ever achieved by banks in Indonesia is 1.80 percent and the highest value is 45.84 percent. The average capital buffer value is 11.15 percent with a standard deviation of 7.01. The standard deviation is smaller than the average value, indicating that the capital buffer variable is normally distributed.

Variable efficiency that measured by operating costs and operating income (BOPO) ratio have a minimum value of 42.0 and a maximum value of 178.43 . This means that from the 150 observational data the lowest BOPO value ever achieved was 42.0 percent and the highest value was 178.43 percent. The average BOPO value is 82.51 percent with a standard deviation of 24.73. The standard deviation value is smaller than the average value, indicating the BOPO variable is normally distributed

The liquidity risk variable has a minimum value of 5.70 and a maximum value of 87.75 . This means that the lowest liquidity risk value ever achieved was 5.70 percent and the highest value was 87.75 percent. The average value of liquidity risk is 34.61 percent with a standard deviation of 17.32. The standard deviation value is smaller than the average value, indicating the normally distributed liquidity risk variable.

\section{A. Classical Assumption}

Test Model testing of classical assumptions applied to structural equations in this study includes multicollinearity tests and normality tests.

\section{> Multicollinearity Test}

The Multicollinearity test aims to test whether the regression model found a high or perfect correlation between independent variables. The following are the results of testing to detect multicollinearity by using a correlation matrix in the program Eviews.

\begin{tabular}{|c|c|c|c|}
\hline & $\mathrm{X} 1$ & $\mathrm{X} 2$ & $\mathrm{X} 3$ \\
\hline & & & \\
\hline $\mathrm{X} 1$ & 1.000000 & -0.233588 & -0.543397 \\
\hline $\mathrm{X} 2$ & -0.233588 & 1.000000 & 0.566049 \\
\hline $\mathrm{X} 3$ & -0.543397 & 0.566049 & 1.000000 \\
\hline \multicolumn{4}{|c|}{$\begin{array}{r}\text { Table 3:- Multicollinearity Test } \\
\text { Source: Output Eviews }\end{array}$}
\end{tabular}

Based on the results of the correlation matrix output above the correlation between $\mathrm{X} 1, \mathrm{X} 2, \mathrm{X} 3$, shows that there is no correlation between independent variables which is high above 0.80 . So, it can be concluded that there is no multicollinearity between independent variables. 
Normality Test

Normality test aims to test whether, in the regression model, the disturbing or residual variables have a normal distribution.

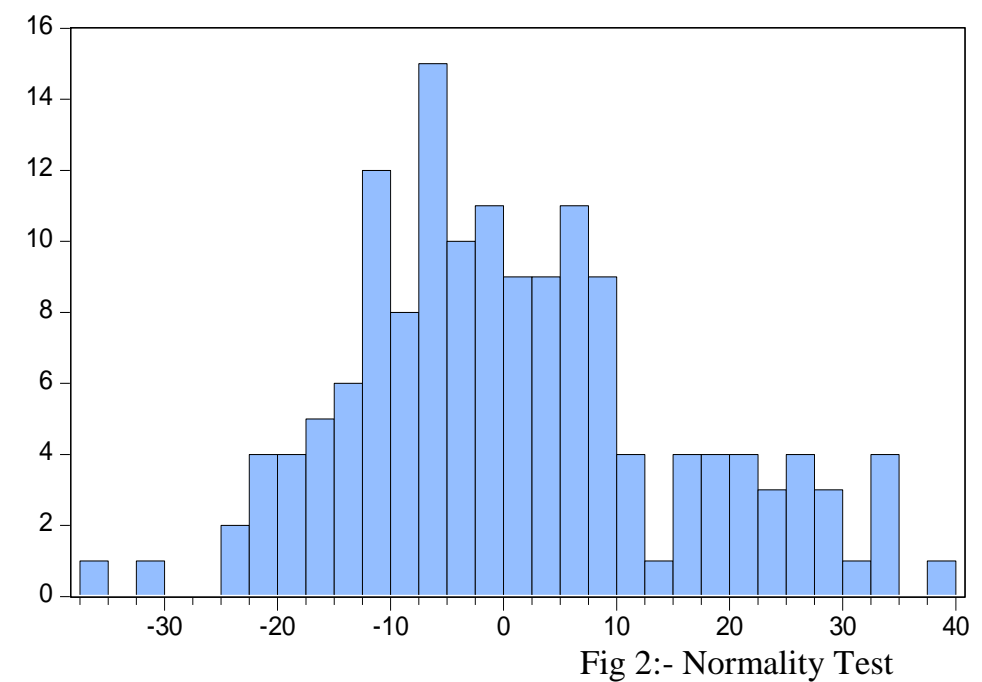

\begin{tabular}{|lc|}
\hline \multicolumn{2}{|l|}{ Series: Standardized Residuals } \\
Sample 2004 2018 \\
Observations & 150 \\
& \\
Mean & 1.055866 \\
Median & -0.487844 \\
Maximum & 37.96228 \\
Minimum & -36.00057 \\
Std. Dev. & 14.67955 \\
Skewness & 0.414216 \\
Kurtosis & 2.857676 \\
& \\
Jarque-Bera & 4.415977 \\
Probability & 0.109922 \\
\hline
\end{tabular}

Fig 2:- Normality Test

Based on the results of testing the classical assumptions, the probability value of Jarque-Bera is equal to 0.109922 . Thus the probability value of Jarque-Bera is greater than alpha 0.05 , so the assumption of normality is fulfilled.

\section{B. Results of Panel Data Regression Analysis}

\begin{tabular}{|c|c|c|c|c|c|c|}
\hline No. & Variable & Coefficient & Std. Error & t-statistic & Prob & Remaks \\
\hline 1 & $\mathrm{C}$ & 37.75228 & 36.12682 & 1.044993 & 0.0297 & Significant \\
\hline 2 & $\mathrm{X} 1 \rightarrow \mathrm{Y}$ & 2.441712 & 1.046852 & 2.332433 & 0.0210 & Significant \\
\hline 3 & $\mathrm{X} 2 \rightarrow \mathrm{Y}$ & 1.091299 & 0.173448 & 6.291780 & 0.0000 & Not Significant \\
\hline 4 & $\mathrm{X} 3 \rightarrow \mathrm{Y}$ & 0.261848 & 0.054866 & 4.772491 & 0.0000 & Significant \\
\hline
\end{tabular}

Table 4:- Results of Data Panel Regression

Source: Data Processed 2020

Based on analysis data, the estimation of the research equation is as follows:

$\mathrm{Y}=37.75+2.44 X_{1}+1.09 X_{2}+0.26 X_{3}$

$>$ Constanta of 37.75 states that if the value of the exogenous variable is considered zero $(X 1=0, X 2=0$, $\mathrm{X} 3=0, \mathrm{X} 4=0$ ) or the value of $\mathrm{X} 1, \mathrm{X} 2, \mathrm{X} 3, \mathrm{X} 4$ remains, then the liquidity risk value 37.75

$>$ Regression variable or bank size (X1) of 2.44 means that if the interest rate variable increase of 1 percent will reduce the value of liquidity risk by 2.44 percent.

$>$ Regression variable or capital buffer (X2) of 1.09 means that if the interest rate variable increase of 1 percent will reduce the value of liquidity risk by 1.09 percent.

$>$ Regression variable or efficiency (X3) of 0.26 means that if the interest rate variable increase of 1 percent will reduce the value of liquidity risk by 0.26 percent.

\section{Hypothesis Testing}

Hypothesis testing is done by comparing the p-value with a significance level (alpha) of 0.05 . If pvalue <alpha 0.05 then $\mathrm{H} 0$ is rejected and $\mathrm{H} 1$ is accepted. Conversely, if p-value > alpha 0.05 , then $\mathrm{H} 0$ is accepted and $\mathrm{H} 1$ is rejected. The results of hypothesis testing in this study are:

\section{Hypothesis Testing 1}

Based on the results of the regression analysis in table 4 above, the coefficient value of the influence of the bank size (X1) on the liquidity risk (Y) is 2.44 with a p-value of $0.02<$ alpha 0.05 . This shows that bank size has a positif and significant effect on liquidity risk. Thus the H1 hypothesis states that bank size has a positive and significant effect on liquidity risk is accepted. This indicates that the greater size of a bank, the more likely it is to experience liquidity risk.

The bank size variable describes the size of the bank based on its assets. There have been several previous studies which examined the effect of bank size on liquidity risk. Sawada (2010) conducted a study relating to liquidity and bank portfolio reductions in the financial system in Japan. The study found that there is a positive relationship between bank size and liquidity. This shows that large banks usually have more loans and have larger financing gaps and this is one of the banking liquidity problems. Zolkifli, Hamidand, and Janor, (2015), also found that bank size and liquidity have a positive relationship. Smaller banks tend to be more limited, so they will be more secure if they hold more liquidity. Delechat (2012) and Vodova (2013) state that smaller banks tend to have higher liquidity reserves. This can be caused by the financial limitations of 
small banks in obtaining funds so that small banks tend to hold higher liquidity.

This is in line with the principle of "Too Big To Fail", where large banks that are considered to be too big to fail will be more trusted by lenders, so large banks tend to have limited motivation to hold high liquidity reserves.

\section{Hypothesis Testing 2}

Based on the results of the regression analysis in table 4 above, the coefficient value of the influence of the capital buffer (X2) on the liquidity risk (Y) is 1.09 with a p-value of $0.00<$ alpha 0.05 . This shows that capital buffer has a positif and significant effect on liquidity risk. Thus the $\mathrm{H} 2$ hypothesis states that capital buffer has a negative and significant effect on liquidity risk is rejected. This indicates that any increase in capital buffer will increase the occurrence of liquidity risk.

The results of this study are supported by research conducted by Jokipii and Milne (2011) on banks in the United States, finding a significant positive and two-way relationship between capital buffer and risk. Zheng et al. (2012) also found a significant and two-way positive relationship between capital buffers and risk in banks in China. In addition, Rime's (2001) study of banks in Switzerland also shows that regulatory pressures affect the level of capital, but do not affect the level of risk.

A positive relationship between capital buffer and liquidity risk can be caused by banks with high levels of capital adjusting capital buffer and risk positively. Banks that have increased their capital targets while increasing their risk exposure. In terms of bank liquidity, there is an imbalance in the collection of DPK funds by lending. High credit growth makes banks have less money to distribute loans. In fact, banking capital will be eroded to serve credit demand.

Charter Value Theory that banks always hold extra capital to secure them from decreasing stability and manage the risk of business failure. Therefore, the bank will maintain its capital in excess of the required minimum capital. The amount of capital owned by the bank effectively protects the depositor against bank failures. Some previous studies found different results with this study. Karim and Verhoeven (2005) state that capital in the banking system can increase depositors' trust and indirectly reduce liquidity risk. Deelchand (2009) states that capital buffer aims to avoid liquidation and bankruptcy as well as capital to be able to compete in global competition. Ahmed, et al (2011) in his research found Capital Adequacy Ratio (CAR) is significant, and negatively related to liquidity risk.

\section{> Hypothesis Testing 3}

Based on the results of the regression analysis in table 4 above, the coefficient value of the influence of the efficiency $(\mathrm{X} 3)$ on the liquidity risk $(\mathrm{Y})$ is 0.26 with a $\mathrm{p}$ value of $0.00<$ alpha 0.05 . This shows that efficiency (BOPO) has a positif and significant effect on liquidity risk. Thus the $\mathrm{H} 3$ hypothesis states that efficiency (BOPO) has a positive and significant effect on liquidity risk is accepted.

This indicates that the higher the BOPO, the greater the liquidity risk. The higher BOPO shows that the bank is less efficient in controlling its operational costs. Inefficiency of bank costs will deplete the profits of banks. This shows that if a bank cannot maintain a rising BOPO ratio, the bank's ability to meet its obligations can be hampered due to lack of revenue due to operational costs that are so large that it will increase the chances of liquidity risk.

\section{CONCLUSIONS}

Based on the results of the research and discussion by the objectives of the study, the following points will be concluded:

$>$ The size of the bank proxied by total assets has a positive and significant effect on liquidity risk. In line with the principle of "Too Big To Fail", where large banks that are considered to be too big to be able to fail will be more trusted by lenders, so large banks tend to have limited motivation to hold high liquidity reserves.

$>$ Capital buffer has a positive and significant effect on liquidity risk. Banks with high levels of capital adjust their capital buffers and risks positively. Banks that have increased their capital targets while increasing their risk exposure.

$>$ BOPO has a significant positive effect on liquidity risk. If a bank cannot maintain a rising BOPO ratio, the bank's ability to meet its obligations can be hampered due to lack of revenue due to operational costs that are so large that it will increase the chances of liquidity risk

\section{REFERENCES}

[1]. Acharya, V.V., Pedersen, L.H., Philippon, T., Richardson, M.P. 2011. Measuring Systemic Risk. American Finance Association. Denver Meetings Paper, pp.1-46.

[2]. Aggarwal, R., Jacques, K.T. 2001. Assessing the impact of prompt corrective action on bank capital and risk. Journal of Banking and Finance, Vol 25 No. 6, pp 1139-1160

[3]. Akhtar, M., Ali, K., Sadaqat, S., 2011. Liquidity Risk Management: A Comparative Study between Conventional and Islamic Banks of Pakistan. Interdisciplinary nJournal of Research in Business, Vol. 1, Issue. 1, pp.35-44

[4]. Anam, A. Khoirul. 2013. Risiko Likuiditas dan Dampaknya terhadap Kinerja Perbankan di Indonesia. Jurnal Dinamika Ekonomi dan Bisnis, Vol. 10, No. 1

[5]. Ayomi, S., dan Hermanto, B. 2013. Mengukur risiko sistemik dan keterkaitan finansial perbankan di Indonesia. Buletin Ekonomi Moneter dan Perbankan, Vol. 16. No. 2, pp. 103-124

[6]. Berger, A and Bouwman, C 2009. Bank liquidity creation, Review of Financial Studies, Vol. 22, No. 9, pp.3779-3837 
[7]. Bernanke, B. 2013. Monitoring the Financial System. Speech At the 49th Annual Conference on Bank Structure and Competition sponsored by the Federal Reserve Bank of Chicago, Chicago, Illinois

[8]. Billio, M., Getmansky, M., Lo, A.W., and Pellizon, L. 2012. Econometric Measures of Connectedness and Systemic Risk in the Finance and Insurance Sector. Working Paper, MIT.

[9]. Bisias, D., Flood, M., Lo, A.W., and Valavanis, S. 2012. A Survey of Systemic Risk Analytics. Working Paper Office of Financial Research, Department of Treasury

[10]. Blancer, N., Mitra, S., Morsy, H., Otani, A., Severo, T. and Valderrama, L. 2013 Systemic Risk Monitoring (SysMoll) Toolkit, A User Guide, IMF working paper $\mathrm{WP} / 13 / 168$

[11]. Deelchand, Tara dan Carol Padgett. 2009. The Relationship between Risk, Capital and Efficiency: Evidence from Japanese Cooperative Banks. ICMA Centre Discussion Papers in Finance DP200912.

[12]. Diamond, D. W., and Rajan, R. G. 2001. Liquidity risk, liquidity creation, and financial fragility: $a$ theory of banking, The Journal of Political Economy,109,2,p. 287-327.

[13]. Ghosh, Amit., 2015. Banking-industry specific and regional economic determinants of Non-Performing Loans: Evidence from US States, Journal of Financial Stability, 20, p. 93-104

[14]. Ghosh, Amit. 2016. Capital Buffer, Credit Risk and Liquidity Behaviour: Evidence for GCC Banks, Comparative Economic Studies, pp.1-31

[15]. Iqbal, Anjum. 2012. Liquidity Risk Management: A Comparative Study Between Conventional and Islamic Bank of Pakistan. Global Journal of Management and Business Research, Vol 12 No 5, pp 54-64.

[16]. Judisseno, Rimsky K. 2005. Pajak dan Strategi Bisnis. Edisi Revisi. Jakarta: Gramedia Pustaka Utama.

[17]. Kaufman, George. G. and K. E. Scott. 2003. What Is Systemic Risk, And Do Bank Regulators Retard Or Contribute To It?. The Independent Review, Vol 8. No. 3, ISSN 1086-1653 